\title{
Petruskova esejistika
}

\author{
HELENA KUBÁTOVÁ
}

Miloslav Petrusek vládl jedinečným uměním napsat sociologický esej. Napsal jich spoustu, ostatně i kniha Společnost a kultura z roku 2012, která u př́ležitosti udělení Ceny Vize 97 vychází, vlastně představuje souhrn esejů.

Pan profesor eseje nejenom psal, ale nad rolí a postavením sociologického eseje se rovněž zamýšlel. Například v eseji o eseji Esej v sociologii a společnost $v$ eseji uvažuje nad tím, že a proč je esejistický styl vylučován $\mathrm{z}$ vědeckého diskurzu, proč se málokdo do psaní sociologických esejů pouští, a to nikoliv jen proto, že sociologická esejistika vyžaduje specifické nadání, ale také proto, že eseje obvykle neotisknou v impaktovaných časopisech. Ostatně Petruskova esej o eseji končí chmurnou vizí budoucnosti sociologického eseje: „Jak že končí Gogolův Revizor? Smutno na tomto světě, pánové. Smutno, pokud jde o budoucnost sociologického eseje, ale jinak veselo, veselo, k popukání veselo..." [Petrusek 2008: 57].

Sociolog Petrusek ovšem nesoudil, že sociologický esej může nahradit standardní sociologické psaní sociologických traktátů a zpráv ze sociologických výzkumů, ostatně sám napsal řadu knih standardním stylem a jeho zásluhy na badatelském poli jsou všeobecně známé. Esej nijak neupřednostňoval, jen soudil, že esej může, vlastně musí: „otevř́t nápaditě nový problém, $\mathrm{z}$ nového zorného úhlu ukázat problém zdánlivě již vyřešený, inspirovat čtenáře k myšlenkovému dialogu s autorem, nabízet nestandardní, ale ještě neověřená řešení, provokovat a zejména inteligentní a duchaplnou formou žádat o spoluúčast a porozuměni'" [Petrusek 2008: 49].

Například v eseji Proč lidé naší doby potřebují mýty? tedy navzdory rozmachu vědeckého poznání, vědeckého obrazu světa, vědecké metody a rozumu, používá modelový esejistický paradox: „Jsme paradoxně sevřeni z jedné strany odmítáním racionality osvícenství, buditelství, vysoké kultury, ale i prostého vědomí odpovědnosti, a na druhé straně slepou a nepřiznanou vírou, že překročíme-li všechny meze, věda nás zase uzdraví. Tatáž věda, kterou jsme ve jménu postmoderní mytologie strhli z jejích nadpozemských výšin, avšak která nám konec konců toto všechno umožnila: věda se ve svých důsledcích proměnila v mýtus" [Petrusek 2012a: 79].

Petruskovy sociologické eseje také ukazují způsob jeho uvažování - tedy uvažování, myšlení na pomezí, např́iklad reflexe literatury (beletrie), umění, filosofie, historie, což ukazuje, že cenu dostává právem, nebot svým dílem dokázal překračovat tradiční rámec vědeckého poznání a poukazovat na širší souvislosti jevů a věcí. Petruskovy eseje ukazují na množství a šírku témat, jimiž se zabýval, na která myslel a o nichž uvažoval a tudíž na jeho rozsáhlé znalosti nejen sociologie a společnosti, nejen z hlediska sociologického.

Jedním ze základních znaků eseje je to, že v eseji autor může - ba musí - vyjádřit osobní postoj. Také tím se esej liší od standardního sociologického psaní, v němž obvykle není místo - a snad i právem - pro osobní postoj autora. Čteme-li Petruskovy eseje, pak nespatříme jen šíri jeho vědomostí, ale mnohdy také jeho mravní postoje, co ho těšilo a z čeho měl obavy. 
$\mathrm{V}$ dalším eseji podle mého soudu varovném O teroristech všedního dne a „měkké devia$c i$ “ se zamýšlí nad snahou společností, v nichž žijeme, vyjmout z působení mravní normy a učinit je tak mravně indiferentními; př́kladem mu je pokus - bohužel úspěšný - vyjmout podstatnou část ekonomických aktivit z mravní kontroly, aby se co nejrychleji všechno zprivatizovalo. Závěr eseje je pro esejistický styl příznačný: „Jedna z důležitých ctností a povinností sociologů je odpovědnost - a odpovědný může být jen člověk příčetný. Zachování prŕíčetnosti, tedy konec konců zdravého rozumu, se tak stává podmínkou nutnou našeho slušného přežití na této planetě: to jediné, čím se můžeme bránit rozvratu řádu a sebezáhubě je rozum, poznání a usilování o pravdu“ [Petrusek 2001: 117]. Petrusek nám tak ve svých esejích zanechal nejen svůj myšlenkový, ale i mravní odkaz.

Závěrem lze konstatovat, že Miloslav Petrusek sociologii nikdy nepoužíval samoúčelně, ale vždy jako nástroj, který má sloužit pro vysvětlení a porozumění společnosti. Mnohým z jeho esejů mohou rozumět i laici, lidé, kteří se o společnost zajímají a kladou si otázky, přičemž mohou zjistit, že jsou to legitimní otázky, nebot’ si je klade i profesor sociologie, jenž př́ípadně nabízí též jiné otázky, jež je snad do té doby nenapadly, a tak v nás všech nenápadně pěstuje touhu po poznání a porozumění světu našeho života. Kladl si rovněž otázku, jaký bude sociolog budoucnosti a jaká bude sociologie: „Musíme tedy usilovat o to, aby se sociologie neprimitivizovala tím, že se bude zabývat pouze předměty a bude ignorovat celou minulost svého vlastního přemítání a bezpečné stezky svých předchozích výzkumů. Opravdu musíme? A kdo vlastně musí?" [Petrusek 2012b: 144-145].

\section{Literatura}

Petrusek, Miloslav [2001]. O teroristech všedního dne a „měkké deviaci“. In. Kabele, Jiří - Mlčoch, Lubomír (eds.): Institucionalizace (ne)odpovědnosti: globální svět, evropská integrace a české zájmy. Přelom druhého a třetího tisíciletí z pohledu společenských věd. Praha: Karolinum, s. 108-119.

Petrusek, Miloslav [2008]. Esej v sociologii a společnost v eseji. In. Osvaldová, Barbora - Kopáć, Radim: Pokusy a dobrodružství: poznámky k eseji. Praha: Karolinum, s. 47-57.

Petrusek, Miloslav [2012]. Společnost a kultura. Praha: Knihovna Ceny Nadace Dagmar a Václava Havlových Vize 97.

Petrusek, Miloslav [2012a]. Proč lidé naší doby potřebují mýty? In. Petrusek, Miloslav: Společnost a kultura. Sociologické úvahy a eseje. Praha: Knihovna Ceny Nadace Dagmar a Václava Havlových Vize 97, s. 73-84.

Petrusek, Miloslav [2012b]. Sociologie mezi minulostí a budoucností: tradice a perspektivy. In. Petrusek, Miloslav: Společnost a kultura. Praha: Knihovna Ceny Nadace Dagmar a Václava Havlových Vize 97, s. $133-146$. 